\title{
UNIVERSITYOF
}

FORWARD

THINKING

WESTMINSTER用

WestminsterResearch

http://www.westminster.ac.uk/westminsterresearch

\section{EU-Russia Energy Relations in Context}

Dannreuther, $\mathbf{R}$.

This is an Accepted Manuscript of an article published by Taylor \& Francis in Geopolitics, 21 (4), pp. 913-921. The final definitive version is available online: http://www.tandfonline.com/https://dx.doi.org/10.1080/14650045.2016.1222521

(c) Taylor \& Francis Inc.

The WestminsterResearch online digital archive at the University of Westminster aims to make the research output of the University available to a wider audience. Copyright and Moral Rights remain with the authors and/or copyright owners.

Whilst further distribution of specific materials from within this archive is forbidden, you may freely distribute the URL of WestminsterResearch: ((http://westminsterresearch.wmin.ac.uk/).

In case of abuse or copyright appearing without permission e-mail repository@westminster.ac.uk 


\title{
EU-Russia Energy Relations in Context
}

\author{
ROLAND DANNREUTHER \\ Centre for the Study of Democracy, University of Westminster
}

The central focus of this Special Section is an analysis and critique of the dominantly geopolitical and realist explanation of EU-Russia energy relations. The articles all address, whether directly or indirectly, this central theme and offer a number of differing perspectives and approaches. The objective of this final concluding article is threefold; first, to set out the broader international developments in relation to global energy security that have contributed significantly to the tendency towards a geopolitical framing of EU-Russia energy relations; second, to draw out and integrate the various perspectives offered by the different articles in this special section and to highlight the main findings and conclusions; and third, to assess what implications there are for analysing and reconceptualising European and international energy security in the light of these findings and conclusions.

\section{The return of energy geopolitics}

In terms of recent history, the increase in tensions over EU-Russia energy relations has to be understood as part of a wider global phenomenon. During the 1980s and 1990s, oil prices were generally low, OPEC's power was greatly reduced not least due to increased non-OPEC production, and the dominant political and economic ideology promoted liberalization, deregulation and privatisation. The collapse of the autarchic Soviet system was just the most dramatic example of the apparent ascendance of liberal capitalism over alternative statist economic systems. The hitherto secretive and state-controlled Soviet energy production was made open to private and foreign investors for the first time since the Bolshevik revolution. Globally, fears of energy security appeared to have been replaced by a general optimism that the newly freed global markets would ensure energy security and would frustrate geopolitical or neo-mercantilist attempts to disrupt the reliable supply of energy to world markets. ${ }^{1}$

This optimism was, though, severely dented during the 2000s. From a low point of under $\$ 10$ a barrel in 1998, oil prices rose rapidly during the decade to reach a peak of $\$ 148$ a barrel in 2008. This strengthening of demand for oil and other energy resources, and the resulting impact on prices, shifted the balance of power significantly from the energy-importing to the energy-exporting states. As a 
result, a significant number of energy-producing states sought to strengthen state control and influence over their domestic energy sectors. The strengthening of the Russian state's control over its oil sector, most clearly evident in the dismantlement of Yukos and its integration into the state-owned oil company, Rosneft, was part of a broader global phenomenon of 'resource nationalism' and the assertion of sovereign rights over national natural resources. In Latin America, in countries like Venezuela or Bolivia, and in Central Asia and Africa, there were similar moves towards greater state control and the weakening or barring of private and foreign access to resources. ${ }^{2}$ The rise in resource nationalism also often merged with a more assertive anti-Western political agenda, emboldening populist authoritarianism and statist economics. As such, the growing opposition to the West in Russia under Putin's rule was part of a more general global phenomenon.

The 2000s heralded another significant shift in global energy politics. This was the ascendance of China, and other emerging powers such as India, as major energy consuming states. Previously, the main energy-importing states were Western states, most notably the United States, Europe and Japan. In the major energy security crises of the 1970s, it was natural that the West should act collectively and in solidarity to respond to these crises. In the 2000s, the dynamics were fundamentally different. It was now emerging Asia, particularly China, where global economic growth and energy demand were exponentially increasing. The new consumers, such as China, did not necessarily share the dominant Western approach to energy security and were willing to adopt a more neo-mercantilist and geopolitical approach. ${ }^{3}$ Their preferred vehicles for ensuring energy security tended also to be stateowned national oil companies rather than the Western preference for private international oil companies. ${ }^{4}$ Russia was again not unusual among oil and gas-producing states to see China's rapidly growing energy import demands as a major opportunity not only economically but also politically.

For the particular case of Russia, these global trends promoting a geopolitical approach to energy security also had regional drivers and dynamics. During the 2000s, Russia became increasingly estranged from European and Euro-Atlantic integration processes. As NATO and the EU expanded and incorporated more members from Central and East Europe, so the relationship between Russia and Europe, and between Russia and NATO and the EU, became more tense and distrustful. There was as a consequence, a significant shift in the quality of relations between the EU and Russia from the 1990s to the 2000s which mirrored the growing levels of anxiety in the EU over energy security. During the 1990s, the EU generally approached Russia with a benign and sometimes indulgent paternalism, believing that Russia would eventually follow the path of the other CEE states in converging with Western economic and political values. The energy inter-dependence between Russia and EU was viewed, in this period, as a major driver and catalyst for such convergence. However, by 
the late 2000s, and particularly after the series of gas disputes between Russia and Ukraine, the EU increasingly viewed Russia as moving in a more isolationist and exceptionalist direction, hostile to European values. ${ }^{5}$ In this changed context, the energy inter-dependence became viewed as a serious source of European vulnerability through which Russia could assert its interests and influence and weaken European solidarity, particularly among CEE states.

The overall consequence of these various global and regional dynamics is that EU-Russia energy relations have been increasingly framed in geopolitical terms. The dominant picture is of two power centres, Russia and the EU, following and promoting two contrasting models and paradigms for European energy security. ${ }^{6}$ The EU is presented as a defender and promoter of a classical liberal framework, where energy security is assured through liberalization, deregulation and promoting transnational market and regulatory frameworks. Russia, in contrast, is presented as promoting an unreformed geopolitical and realist approach, seeking to enhance its influence and power through the 'Achilles heel' of Europe's energy dependence on Russia. In this geopolitical struggle, Ukraine acts as the strategic epicentre, a country pulled variously to Europe or back to Russia, and where the major instrument that Russia has is its 'gas weapon' so as to place pressure on both Ukraine and the EU.

\section{Going beyond energy geopolitics: the contributions of this volume}

It is this dominant geopolitical and realist framework that the various contributions to this Special Section seek to assess and critique. One criticism of the geopolitical and realist traditions is its tendency towards ahistoricity, failing to take into account the historical evolution of international politics. In the case of Russian-EU energy relations, Sharples provides a critical historical perspective by comparing the European and the Chinese gas markets for Russia, making the often forgotten point that almost no progress has been made in developing the Chinese market for Russian gas. The infrastructure required for significant Asian exports is decades away, and it is improbable that the gas currently directed to European markets will be transported eastwards for Asian markets. The idea of a simple geopolitical switch by Russia from Europe to China lacks economic logic.

It is not just that Russia's European markets are more developed and intensive compared to those in China. It is also that Russian-EU gas relations have a historical depth and institutionalisation that creates its own logics of continuity and durability. The origins of Europe's dependence on Russian gas goes back to the heights of East-West hostility during the Cold War in the 1970s and 1980s. In spite of this highly distrustful political environment, there was at that time a genuine and compelling mutual economic interest that underpinned this commercial relationship. The Soviet Union had abundant 
supplies of gas but lacked the capacity to construct the steel pipes and compressor stations to keep the gas flowing, while Europe had the market for gas and the technology to ensure that the gas reached these markets. As Sharples notes, 'The relationship between the Soviet gas industry, with its seemingly limitless gas reserves, and European energy companies, with their technology and willingness to pay hard currency for Soviet gas, paved the way for the development of Soviet gas exports to Europe' ${ }^{7}$

This path dependency continues to the present day. Alternatives to Russian gas, if the EU really sought to divest from Russia, would be expensive and difficult to set up and create new vulnerabilities. It would also take away one of the potentially most significant avenues for the EU to influence Russian behaviour. In this regard, Russia has similarly a strong interest in ensuring that, despite any political differences it might have with the EU or NATO, it remains a reliable and trustworthy energy supplier. Casier makes the interesting point that, at precisely the moment in 2014 when a serious geopolitical and military conflict did split the EU and Russia, the perception that the threat came from Russia's energy 'weapon' actually decreased. The dominant mood in both Russia and Europe was that it was important to keep energy out of the conflict and to ensure that this vital economic inter-dependence was not harmed by the deterioration in political relations. Drawing broader conclusions from this, Casier highlights how the perception of Russia as an energy security threat has generally acted as a proxy for a more generic and ideological disenchantment with Russian political behaviour rather than a concrete analysis of the fundamentals of Russian-EU energy relations. ${ }^{8}$ Once a real-life political and military crisis emerges, as in 2014, the durability and embedded institutionalisation of EU-Russia energy relations has actually been affirmed rather than undermined.

If there is an important 'path dependency' between Western Europe and Russia in terms of its energy relations, this is even more the case potentially for the former Warsaw Pact and Soviet states who are now part of the EU but whose energy relations were constructed during the Soviet period. Kama brings out this complex inter-relationship through an analysis of Estonia's energy security policy. Estonia's has a deserved reputation as one of the most radical of the CEE countries in implementing the neoliberal market policies of the EU but, as Kama notes, its energy security policy is in marked contrast to this. Estonia has significant domestic supplies of shale oil, which make up almost $90 \%$ of electricity production, and the Estonian government has been strongly committed to maintaining state control and resist EU policy prescriptions for liberalization, unbundling and privatisation. Kama highlights the paradox of an industry which was created by the Soviet Union, inherits much of the negative environmental costs from Soviet production practices, but is strongly defended as a bulwark of Estonia's independent sovereignty, patrimony, and a guarantor of its national security. The result is an energy security policy which is closer in spirit to that of a Russian statist than a liberal EU model. As 
in Russia, the dominant political tendency is the desire for state control, there is a close and intimate relationship between the national oil company and the state and a strong political and economic resistance to liberalization and diversification.

The case-example of Estonia illustrates the wider point that each individual country in CEE and in the EU has a complex set of historical 'path dependencies' in its energy sector, specific and particular state-company and state-market relations and philosophies, and differing national conceptions of energy security. Energy security, and the appropriate energy relationship with Russia, is not something simply formulated and imposed supranationally by the EU; it is debated, formulated and implemented at national levels influenced by the relative power of differing constituencies within the country. This does not mean that the energy security debate is static and pre-determined. Kama notes that in Estonia there is a dynamic and evolving debate but that the choices are 'not so much foreclosed by supranational authorities than made through the reconfiguration of national expertise, during which the binary between market and non-market modes of energy governance is vigorously tested and renegotiated'". Similarly, in other CEE and EU states, it is the specificities of the national context and the political culture which is critical for understanding the particular and distinctive approach to Russian-EU energy relations. Geopolitics is only one, and not always the most important, dimension of this.

This brings out a more general theme that emerges from this Special Section. This is the need to recognize the complexity of the mix of actors and processes in understanding the phenomenon of Russian-EU energy relations. A geopolitical framing tends to simplify this more complex reality. Casier notes that the actors involved are not just governments and companies but include consumers, retailers and regulators, and their interaction is framed not just by issues of ownership and control but through a complex array of regulatory and pricing mechanisms. This complexity of the policy environment is brought out particularly well by Romanova, who argues that Russia adopts not only geopolitical but also non-geopolitical legalistic and technocratic approaches. For Romanova, Russia and the EU are influenced in their policy-making by a geopolitical and ideological agenda but that there is also a tendency to resolve differences pragmatically through more legalistic and technocratic approaches. In this more complex environment, actors like Gazprom, who are generally viewed as mere instruments of the Russian state, emerge as having a degree of autonomy in seeking to find pragmatic solutions and compromises over contested issues between Russia and the EU.

The nature of Russian-EU energy relations needs also to incorporate the differences between differing issue areas. Romanova extends her threefold policy framework (geopolitical, legalistic and technocratic) to illustrate how Russia has adopted different approaches to different issues. ${ }^{10}$ In her 
analysis, these differing issues differentiate the Russian approaches between issues over ownership as against the operation of grids; between the Nord Stream as against South Stream; and over gas pricing mechanisms. The need to incorporate this more complex and differentiated understanding of RussianEU relations is developed further in the article by Hadfield. She makes an important distinction between those issue areas of EU-Russia interaction which illustrate progressive and regressive EURussia strategic cultures. In the former progressive strategic culture, there are the EU policies of the Northern Dimension, the Partnership and Cooperation Agreement (1994), and the EU-Russia energy dialogue. The more regressive and conflictual category includes initiatives like the Energy Charter Treaty, the European Neighbourhood Policy, and the EU acquis in the internal energy market with the successive liberalisation packages. Hadfield argues that the more positive gains in developing a common strategic culture are not forgotten even at times of considerable tensions and conflict, since 'the EU-Russia strategic energy culture is [...] never more evident than when both sides are locked in vicious agreement about how to interpret and manage it'. ${ }^{11}$

The final layer of this more complex framing of Russian-EU energy relations includes an accurate assessment of European dependence on Russia and the particularities of national and European energy systems. Casier notes that the perception of a geopolitical Russian energy threat needs to be put into perspective taking into account the fact that Russia only accounts for $6.5 \%$ of the primary energy consumption in the EU, and its share of gas imports is about one third (31.5\%). Even when certain CEE states are 100\% dependent on Russian gas imports (Estonia, Lithuania, Latvia and Finland), only Latvia at $32 \%$ has more than a $30 \%$ dependence on Russia for its overall energy consumption. As Kama highlights in her article, Estonia has a significant degree of energy independence which is it is very reluctant to lose. And some of the CEE countries that have the greatest suspicions and distrust of Russia's energy policies, such as Poland, actually have some of the lowest levels of energy dependence on Russia. As the Polish case shows, the construction of Russia as an 'energy security threat' is not always entirely politically innocent. As Maltby and Khrushcheva note, Poland's continuing dependence on coal for its electricity generation has resulted in seeking to water down the EU's decarbonisation agenda, which can usefully draw on the argument that Poland's indigenous supplies of coal help to provide security against excessive gas dependence on Russia.

This leads to the final point that energy security has also to incorporate the complexity not only of energy systems but also the interaction of these energy systems with human systems and to incorporate potential ensuing negative externalities, such as the threat of unmitigated climate change. Maltby and Krushcheva highlight the fact that the EU and Russia are much further apart in terms of their climate change mitigation and decarbonisation agendas than in their fossil fuel relationship. ${ }^{12}$ While EU has 
taken a strategic lead in climate change negotiations and set out ambitious goals, Russian ambitions and interests in this area are more muted, with support for the agenda being driven by an almost exclusively instrumental rationality whereby decarbonisation supports greater domestic energy efficiency and thus increases the levels of energy exports. For Russia, the EU's decarbonisation agenda is a significant potential threat to future European gas and oil demand. Thus, while decarbonisation is an integral part of the EU's conceptualization of energy security, for Russia it is often viewed as a direct threat to its own energy security concerns. Not unsurprisingly, as Maltby and Khrushcheva note, there has as a result been no effective institutionalization of the Russian-EU non-hydrocarbon energy relationship.

\section{Rethinking Russian-EU Energy Relations}

While it is important to incorporate these differing layers of complexity and differentiation, it is vital not to forget that geopolitics remains central to Russian-EU energy relations. Although there is a tendency to exaggerate Russia as an 'energy superpower', the fact that Russia is a major energy supplier to Europe is a source of its national power and regional influence. But this needs also to be counter-balanced by recognition that the EU's energy market is a source of its own power and strength. The EU policies that structure the regulatory frameworks for this internal energy market, as well as over other issues such as climate change, have powerful independent impacts on interested external stakeholders, not least on Russia. As a non-member of the EU, and not present or part of the policy and governance structures of the EU, Russia has only a limited voice or capacity to influence the eventual decisions taken. Although the EU is often depicted as a 'civilian power', whose influence comes from its 'soft' power as against Russia's promotion of its 'hard power', the EU's regulatory powers in the economic sphere can appear very 'hard' on neighbouring non-EU states.

EU-Russia- energy relations also cannot be divorced from developments of the bilateral relationship more generally. Distrust and suspicion in their mutual energy relations have grown as Russia has become more suspicious about the political and economic intentions of the EU and, for its part, the EU has increasingly viewed Russia negatively as challenging and opposing the EU's core values. In this regard, the Russia-Ukraine gas disputes have tended to be seen as part of a broader struggle between Russia and the EU over whether Ukraine remains umbilically tied to Moscow or moves westwards. Energy and geopolitics have inevitably become fused and integrated, not least in the popular mind. Nevertheless, as this Special Section demonstrates, there has also been a strong resolve, in both Moscow and among EU capitals, to try to 'insulate' these energy relations so they do not become 
victims of the broader geopolitical environment and to reach pragmatic solutions which emphasise the technical and commercial rather than political.

The overarching conclusion that that can be drawn from this Special Section is that it is important to move away from essentialising Russia and the European Union. The EU is composed of a multiplicity of different nation states with their own interests and values, which is particularly evident in their energy sectors which remain a site of considerable national sovereign power. Russia itself is also more differentiated than is often assumed, with differing actors seeking to promote distinctive approaches in their policy making, as is brought out well by Romanova. It is important, therefore, that the general and abstract frames drawn from International Relations, that tends to pit a 'liberal' EU against a 'realist' Russia, are supplemented and qualified by an historically sensitive political economy approach which grounds the analysis in the concrete realities of the historical constitution of the complex web of energy infrastructures and cultures. What emerges from this are patterns of continuity and change which do not follow the presumed trajectories of the 'grand narratives' that mark past and current periods, such as the Cold War and the post-Cold War, or the competing dynamics of globalization and liberalization as against resource nationalism and sovereignty. The underlying reality of Russian-EU relations subverts these expected patterns of behaviour and have a greater degree of durability and sustainability than is often assumed. 


\section{NOTES}

${ }^{1}$ E.L. Morse, 'A new political economy of oil?', Journal of International Affairs 53/1 (1999) pp. 1-29; A.M. Jaffe and R.A. Manning, 'The shocks of a world of cheap oil', Foreign Affairs 79/1 (2000) pp. 16-29.

${ }^{2}$ V. Vivoda,'Resource nationalism, bargaining and international oil companies: challenges and change in the millennium', New Political Economy 14/4 (2009) pp. 517-534; P. Stevens, 'The history of the international oil industry', in R. Dannreuther and W. Ostrowski (eds.) Global Resources: Conflict and Cooperation (Basingstoke, Palgrave Macmillan, 2013).

${ }^{3}$ E.S. Downs, 'The Chinese energy security debate', China Quarterly 177 (2004) pp. 21-41; Dannreuther, R. (2011). "China and Global Oil." Inrernational Affairs 87(6): 1345-1364.

${ }^{4}$ A. Goldstein, 'New multinationals from emerging Asia: The case of national oil companies', Asian Development Review 26/2 (2009) pp. 26-56.

${ }^{5}$ D. Galbreath, 'Putin's Russia and the "New Cold War', Europe-Asia Studies 60/9 (2008) pp. 1623-1630; A. SchmidtFelzmann, 'EU member states' energy relations with Russia: conflicting approaches to securing natural gas supplies', Geopolitics 16 (2011) pp. 574-599; C. Kuzemko, 'Ideas, power and change: explaining EU-Russia energy relations', Journal of European Public Policy 21/1 (2014) pp. 58-75.

${ }^{6}$ D. Averre, 'Competing rationalities: Russia, the EU and 'shared neighbourhoods', Europe-Asia Studies 61/10 (2009) pp. 1689-1713.

7 J. Sharples, 'The Shifting Geopolitics of Russia's Natural Gas Exports and Their Impact on EU-Russia Gas Relations', Geopolitics (this issue).

8 T. Casier, 'Great game or great confusion? The geopolitical framing of EU-Russia energy relations', Geopolitics (2016)

${ }^{9}$ K. Kama, 'Contending Geo-logics: Energy Security, Resource Ontologies, and the Politics of Expert Knowledge in Estonia', Geopolitics (this issue).

10 T. Romanova, 'Is Russian Energy Policy towards the EU Only about Geopolitics? The Case of the Third Liberalisation Package', Geopolitics (this issue).

${ }^{11}$ A. Hadfield, 'EU-Russia Strategic Energy Culture: Progressive Convergence or Regressive Dilemma?', Geopolitics (this issue).

12 O. Khrushcheva and T. Maltby, 'The Future of EU Russia Energy Relations in the Context of Decarbonisation', Geopolitics (this issue). 